\title{
'Who is wise and understanding among you' (James 3:13)? An analysis of wisdom, eschatology and apocalypticism in the epistle of James
}

\author{
Patrick, J Hartin \\ Gonzaga University, Spokane \\ Washington, USA
}

\begin{abstract}
Three questions form the basis of this analysis of the relationship of the Epistle of James to the traditions of wisdom, eschatology and apocalypticism. What kind of traditions are involved in James? What is the world view of James? What audience or community is presupposed by this writing? Foremost is the connection that James demonstrates to the wisdom tradition evident in the Old Testament and extra-testamental literature. In particular two types of wisdom tradition are noted in James: practical wisdom advice as expressed in short sayings, wisdom instructions and admonitions and reflection on the nature of wisdom (1:5-8; 2:1-7; and 3:13-18) as coming from God. Finally, the question of how much apocalyptic symbolism is evident in the eschatological world view of the epistle is addressed.
\end{abstract}

\section{INTRODUCTION}

Much recent research has focused on the traditions of wisdom, eschatology and apocalyptic, especially as they relate to genre (Nickelsburg 1994:715-732). These examinations have argued that such terms do not refer to neatly defined genres as was once thought. Instead, their interrelationship has been the subject of much investigation (Collins 1993:165-185).

This present examination focuses on the Epistle of James and examines its relationship to the three traditions of Wisdom, eschatology and apocalyptic. Can this epistle shed any light upon the relationships between these ifferent traditions? Reference will also be made to the Epistle of Enoch (1 Enoch 92-105) as a help to identify these relationships. 


\section{TRADITIONS REFLECTED IN THE EPISTLE OF JAMES}

\subsection{Wisdom traditions reflected in the text}

Israelite wisdom traditions give evidence of a twofold area of concern: namely the presentation of ethical admonitions and advice, as well as an attempt to reflect upon the nature of wisdom. This wisdom tradition shows that Israel is a daughter of the Middle East for it binds her to her neighbors in its form, structure, and even content. This tradition perseveres in the period between the two testaments and is responsible for the production of more writings which bridge the gap between the two testaments.

A twofold development can be observed within Israelite wisdom thinking (Crenshaw 1976:24-26). The first stage revolved around the notion that the fear of the Lord was the beginning of wisdom. The path to acquiring wisdom is through the acceptance of God, through adherence to the covenant faith. The second stage battles with the question of how knowledge, derived from the realm of human wisdom, can be given the quality of truth. To bridge the gap, as it were, between the divine and the human, the wise postulated the personified figure of wisdom. This heavenly figure dwells in their midst and is responsible for enlightening the minds of the wise. Ben Sirach takes the personification a step forward when Wisdom is seen to dwell above all in Israel. This is achieved through the identification of Wisdom and Torah (Crenshaw 1976:25). These two aspects of wisdom form the focus of attention throughout the wisdom thinking of the Hebrew writings, namely the ethical way of life demanded by wisdom and the personification of wisdom itself.

The Epistle of James is to be viewed against this two-sided concern of wisdom to see how it situates itself in this perspective. Attention will be given to both dimensions, namely (a) the relationship of wisdom and ethics, and (b) the nature of wisdom.

\subsubsection{The relationship of wisdom and ethics}

Some wisdom literature, in particular the books of Proverbs, Qoheleth, and Ben Sirach, aims at providing instruction for the art of living, or the mastery of life itself. The ethical teaching of the wisdom writings has as their goal the leading of a happy existence under the sovereignty of God. This provides the context for all ethical teaching and James, as a wisdom writing, can only be fully appreciated and understood against this background. In James ${ }^{1}$ the ethical is expressed by means of specific forms that owe their origin to the Hebrew tradition. Among these forms in which the wisdom advice is presented are the following: 


\subsubsection{Wisdom sayings}

A wisdom saying arises from experience and draws a conclusion from this experience. Very often it entails giving advice on how to lead one's life. James contains numerous examples of such wisdom sayings. Dibelius, in his commentary on James (1975), argued that these were isolated sayings that did not fit into their context. Originally these sayings might have been independent, but James has carefully brought them together as an intimate part of the context. For example: 'For judgment will be without mercy to anyone who has shown no mercy; mercy triumphs over judgment' (James 2:13). Dibelius (1975:147) argues that this is 'an isolated saying' that has no connection with the themes of the section preceding it. A close examination of this passage, however, shows that this verse does form an essential part of the context where it summarizes the main argument of the pericope, namely not to show partiality in one's actions.

Most often these wisdom statements conclude a pericope by reinforcing the argument. For example: 'And a harvest of righteousness is sown in peace for those who make peace' (3:18). Other similar sayings are : 'For just as the body without the spirit is dead, so faith without works is also dead' $(2: 26)$. 'For where there is envy and selfish ambition, there will also be disorder and wickedness of every kind' $(3: 16)$. This saying ('And a harvest of righteousness is sown in peace for those who make peace' [3:18]) brings together the thought development in this pericope: the gift of wisdom produces the gift of righteousness which is illustrated by peace. At the same time this saying bridges the gap to the next pericope: chapter 3 concludes with a reference to peace, while chapter 4 opens with the question on the origins of conflicts: 'These conflicts and disputes among you, where do they come from?' (4:1).

\subsubsection{Wisdom admonitions}

Admonitions lay emphasis on the didactic element and call for obedience to and implementation of the advice. Usually a reason is added to support this admonition. They are eminently suited to the wisdom style that offers practical advice to its readers. James finds this form to be the most appropriate way to express his paraenetical advice. For example:

* 'My brothers and sisters, whenever you face trials of any kind, consider it nothing but joy' (1:2). This passage continues with numerous other admonitions: 'and let endurance have its full effect, so that you may be mature and complete, lacking in 
nothing' (1:4); 'If any of you is lacking in wisdom, ask God, who gives to all generously and ungrudgingly, and it will be given you' (1:5); 'But, ask in faith, never doubting, for the one who doubts is like a wave of the sea, driven and tossed by the wind' $(1: 6)$.

* James 1:19-27 contains a series of admonitions that revolve around the threefold saying: 'Let everyone be quick to listen, slow to speak, slow to anger' $(1: 19)$. This pericope considers each one of these phrases which give rise to admonitions. Dibelius (1975:109-110) has argued that this three-part saying is constituted from traditional wisdom sayings.

* James 4:7-10 contains ten imperatives that include related admonitions: 'Submit yourselves therefore to God....Humble yourselves before the Lord, and he will exalt you.' All the admonitions are contained between these parallel admonitions to submit to God.

* The Epistle of James ends with various admonitions on such themes as not taking oaths; the exhortation to prayer; and finally concluding with the admonition: 'You should know that whoever brings back a sinner from wandering will save the sinner's soul from death and will cover a multitude of sins' (5:20). By following these admonitions and the way of life that this epistle outlines, the reader can hope for salvation.

A twofold perspective emerges from this examination. A focus on the present shows the readers the type of life they are to lead now. Secondly, a vision onto the future looks toward the attainment of salvation. Noteworthy is the appropriation of a new dimension into traditional wisdom reflection: the world view of wisdom has been broadened to include the eschatological dimension. In James (as with the Sayings Gospel Q) the death and resurrection of Jesus does not influence the wisdom world view. Instead, the future, eschatological age exercises a specific impulse upon James.

\subsubsection{Beatitudes}

The beatitude is a form common to wisdom literature. Although the literary form of a beatitude has been shown to be at home in both the Old Testament and the Greek worlds (Hauck 1967:362-364), it is really in the world of the Hebrew writings of the 
Old Testament and intertestamental period that the closest analogies are found. In comparing the form of the beatitude in the Old Testament with that in the New Testament, one striking difference emerges. In the New Testament the perspective has changed from the blessing conferred in the present, to one that awaits a fulfillment in the future eschatological age (Hauck 1967:367). For example, in Ben Sirach 26:1 the blessing is clearly upon the present: 'Happy is the husband of a good wife; the number of his days will be doubled' (see also Pr.14:21). Whereas the New Testament envisages the blessing largely for the future: 'Blessed are you who are poor, for yours is the kingdom of God' (Lk 6:20).

There are two occasions where the word $\mu \alpha \kappa \alpha$ olos occurs in the Epistle of James:

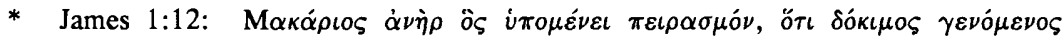

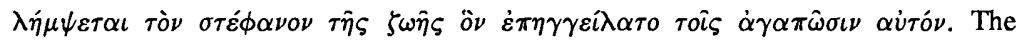
structure conforms to the normal New Testament way of expressing the beatitude. (See for example the Beatitudes in Matthew 5:2-12 and Luke 6:20-23: $\mu \alpha \kappa \dot{\alpha} \rho \iota \varsigma^{\circ}$ appears first, followed by the person who is considered blessed (in this instance the general expression $\dot{\alpha} \nu \eta \dot{\rho} \rho$ ), and then the reason for the blessedness is expressed (Hauck 1967:367). In this beatitude the eschatological dimension dominates and transforms this wisdom form. The wisdom statement is referred to the future, producing a definite contrast between present and future. An eschatological correlative is evident here: the blessedness projected onto the future stands in opposite correlation to what is experienced in the present. The promise is made to those who endure trial now that they will inherit 'the crown of life.' In this there is a closeness to the expression of the beatitudes in the Sayings Gospel $Q$ as well as in the Book of Revelation, where they occur within an eschatological framework (Hauck 1967:367-370).

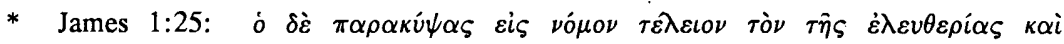

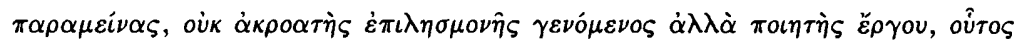

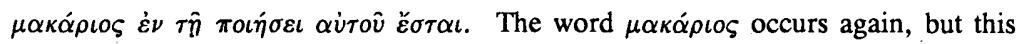
time it is used not in the form of a beatitude, but rather as an adjectival description. The blessing refers to the future: one's present actions bring the promise of future blessings. Again the perspective is that of the eschatological correlative. 
Hauck (1967:369) comments on these two verses in James 1:12 and 1:25: 'Similarly, those who stand fast are called blessed in James 1:12, for their earthly endurance brings them eternal salvation. The thought of a sure reward is also present when the righteous doer is called blessed in James 1:25. In all these verses the light of future glory shines over the sorry present position of the righteous. Thus the New Testament beatitudes are not just intimations of the future or consolations in relation to it. They see the present in the light of the future.'

These two occurrences of $\mu \alpha \kappa \alpha \dot{\alpha} \rho \iota_{S}$ in James show clearly the eschatological correlation between the present and the future. The promise of blessedness is reserved for the future, to be attained as a consequence of what one does now. This future lies in that realm of God's kingdom where those who are blessed will inherit 'the crown of life.' The eschatological provides the motivation for the present way of life. The wisdom advice and ethical exhortations are all governed by the eschatological perspective. The traditional wisdom world view taken over from the Old Testament has now been injected with an eschatological world view that provides the overlay and the motivation for their actions in the present.

\subsubsection{Woes}

This literary form is evident in both the prophetic and wisdom traditions. The Epistle of James has brought this literary form into harmony with the wisdom tradition. Two examples are evident in the epistle:

James 4:13-17 addresses a condemnation against false confidence. He opens this address with a call 'Come now!' ('A $\gamma \varepsilon \nu \bar{v} \nu$ ). This is a phrase not found elsewhere in the New Testament, apart from the beginning of the next chapter (James 5:1-6). While it is found elsewhere in Greek literature (for example, in the diatribe, Epictetus 1.2.20; 1.6.37; 3.24.40; as well in as the Syblline Oracies 3:562 [Davids 1982:171]), the form of this pericope is rather to be associated with the prophetic modes of address. As Dibelius (1975:231) says: ' $4: 13-16$ is delivered in the style of a prophetic address. The prophet cries out his words among the masses, unconcerned about whether his accusations reach the ears of those whom he accuses.' I would see this expression $(\mathrm{A} \gamma \varepsilon \nu \hat{v} \nu$ ) corresponding to the prophetic form of address 'Woe, to you...' (such as Isaiah 5:8ff).

He operates in the same way in which the prophets of the Old Testament presented their message. In the prophetic literature the criticisms are sharp. For example, Micah 6:11: 'Can I tolerate wicked scales and a bag of dishonest weights?'; Amos 8:4-6: 'Hear this, you that trample on the needy, and bring to ruin the poor of the land, 
saying, 'When will the new moon be over so that we may sell grain; and the sabbath, so that we may offer wheat for sale? We will make the ephah small and the shekel great, and practice deceit with false balances, buying the poor for silver, and the needy for a pair of sandals, and selling the sweepings of the wheat.' Ezekiel singles out the great trading city of Tyre for condemnation: 'Now you, mortal, raise a lamentation over Tyre, and say to Tyre, which sits at the entrance to the sea, merchant of the peoples on many coastlands' (27:1-36).

In the wisdom literature the accusations are equally forceful: Proverbs 20:23: 'Differing weights are an abomination to the Lord; and false scales are not good.' Ben Sirach devotes a series of chapters to the temptations that come from commerce (Sirach 26:29-29:28). He criticizes very sharply the way of life of the trader: 'A merchant can hardly keep from wrongdoing, nor is a tradesman innocent of sin' (26:29).

The Book of Revelation continues this tradition of condemning merchants in the criticisms against Babylon: 'And the merchants of the earth weep and mourn for her, since no one buys their cargo anymore, cargo of gold, silver, jewels, and pearls, fine linen, purple, silk and scarlet, all kinds of scented wood, all articles of ivory, all articles of costly wood, bronze, iron, and marble, cinnamon, spice, incense, myrrh, frankincense ...' (18:11-13).

The prophets often directed their attacks outside of the community of Israel, with no real expectation that the nations whom they addressed would in fact turn from their ways. Instead, these attacks operate as a call for the people of Israel to heed the warnings and correct their way of life. James provides his readers with a teaching that calls for faith to be carried out in action. By putting their trust entirely in themselves, they reject God. A similar way of address is found in 1 Enoch in the context of a series of woes. In 94:1 Enoch speaks to his 'sons', then in 94:8 he changes his address to embrace the rich: 'Woe to you rich,' and he continues with this second person address. The same change of address is observable between 95:3 and 96:1-3. In these passages the audience envisaged is the righteous and the suffering. But, within the same context an address is made to the rich and sinners: $95: 1,2,4-7 ; 96,4-8$ and 97:2-10. As in the Epistle of James, so here in 1 Enoch, a distinction is drawn between the community and those rich outside the community. The address to the rich outside the community acts more as a teaching for the members of the community of Enoch than as an appeal for the rich outside the community to change their way of life. While James is not attacking a specific incident within the community of his audience, he is warning them in prophetic style against an attitude evident within the world which they are to avoid. Faith and action are not to be separated. 
A second woe (A $\gamma \varepsilon \nu \hat{v} \nu \ldots$ James 5:1-6) follows immediately on the previous condemnation of those who fail to put their trust in God. The previous pericope emphasized the need to place trust solely in God. This pericope illustrates how the rich place their trust, not in God, but in their riches. The eschatological references are much more specific and intense. In language that bears close similarities to the prophets, this pericope opens with a reference to 'the miseries that are coming to you' (5:1) and continues with reference to 'the last days' (5:3) that are graphically depicted as 'a day of slaughter' (5:5). In contrast to the attitude of the rich stands the attitude of the righteous one who offers no resistance. The implication given is that the righteous will be justified in the eschatological age. The same promise is made to the righteous in 1 Enoch 92-105. The eschatological perspective is pursued in the following pericope: 'Be patient, therefore, beloved, until the coming of the Lord' (5:7-11).

In James wisdom emerges as a strategy wherein advice is offered to the hearer on how best to lead one's life. Faithful to this strategy James uses not just the wisdom tradition, but other traditions as well, namely the eschatological and the prophetic. By incorporating the eschatological and the prophetic world views within the wisdom perspective, the call to a specific way of life becomes all the more urgent. The eschatological provides the motivation: judgment in the future depends upon the way one leads one's life here and now. The use of prophetic imagery and terminology reinforces this urgency: 'You have lived on the earth in luxury and in pleasure; you have fattened your hearts in a day of slaughter' (5:5).

\subsubsection{Wisdom forms of comparison}

The use of different forms of comparison is characteristic of all wisdom writing. The reader is actively involved in the processes of discovering the relationship intended by the speaker. The Epistle of James makes use of different types of comparison among which three are to be noted:

First, there is the simple contrast that calls the reader to adopt a specific action. 'But ask in faith, never doubting, for the one who doubts is like a wave of the sea, driven and tossed by the wind' (1:6). 'But, be doers of the word, and not merely hearers who deceive themselves' (1:22). 'Adulterers! Do you not know that friendship with the world is enmity with God?' (4:4).

Secondly, there are explicit comparisons such as similes or metaphors that are characteristic of James's style of writing. '... for the one who doubts is like a wave of the sea, driven and tossed by the wind' $(1: 6) ;$ '...the rich will disappear like a flower in the field' (1:10); 'It is the same with the rich; in the midst of a busy life, they will wither away' (1:11). 
Finally, like the Gospels the Epistle of James also uses the parabolic method of comparison and instruction. Again the reader becomes actively involved in discovering the intended meaning.

* 'For if any are hearers of the word and not doers, they are like those who look at themselves in a mirror; for they look at themselves and, on going away, immediately forget what they were like' (James 1:23-24). The comparison illustrates the need to put into action what has been heard: to be a doer of the word.

* 'For if a person with gold rings and in fine clothes comes into your assembly, and if a poor person in dirty clothes also comes in...' (James 2:2-4). Discrimination on the basis of wealth is clearly condemned in this comparison.

* 'If a brother or sister is naked and lacks daily food, and one of you says to them, 'Go in peace; keep warm and eat your fill,' and yet you do not supply their bodily needs, what is the good of that? So faith by itself, if it has no works, is dead' (James 2:15-17). By means of this parabolic illustration (Ropes 1916:206), James argues his wisdom perspective: faith must be put into action to be considered true faith.

These wisdom forms (sayings, admonitions, beatitudes, woes, and forms of comparison) all demonstrate the Epistle's firm roots in the wisdom tradition. At the same time wisdom functions as a strategy that integrates aspects taken from the prophetic and eschatological traditions in order to show how faith must give direction to action. I shall return below to draw out further the significance that the integration of the eschatological perspective within the wisdom tradition had for James.

\subsubsection{The nature of wisdom}

The wisdom tradition going back to the Book of Proverbs (chapter 8) also demonstrates another development, namely a reflection upon the nature of wisdom itself, a speculation that would ultimately lead to a personification of wisdom. An aspect of this tradition is evident in James, though not as prominent as the practical aspect of wisdom. Two pericopes in James (1:5-8; and 3:13-18) offer a definite reflection on the nature of wisdom. 


\subsubsection{Wisdom as a gift from God (1:5-8)}

In the spirit of absolute certainty in being heard, one approaches God to request God's wisdom. In contrast to this confidence appears the person who doubts, the one who is

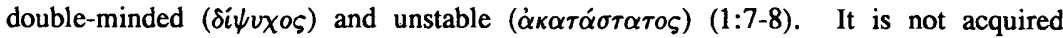
through self-realization, but comes from God in prayer. Wisdom is above all God's gift. 'All wisdom is from the Lord, and with him it remains forever' (Sir 1:1. Cf also Sirach $1: 26 ; 17: 11 ; 24: 2 ; 39: 6$. The Book of Wisdom also develops this perspective: 'Therefore I prayed, and understanding was given me; I called on God, and the spirit of wisdom came to me' [Wis 7:7; cf also 8:21; 9:4]. James reflects this Jewish wisdom tradition that sees God as the giver of all wisdom, giving 'generously and ungrudgingly' $(1: 5)$. The response to this belief requires one to pray in faith for what one needs. Again James is reliant upon the Jewish wisdom tradition that encourages constant prayer: 'Do not grow weary when you pray' (Sir 7:10). This same thought reappears in James 5:16 'The prayer of the righteous is powerful and effective.'

This request for the gift of wisdom must be viewed in the context of the previous pericope which called on the hearer to strive for perfection, a perfection that is the consequence of steadfastness: 'and let endurance have its full effect, so that you may be mature and complete, lacking in nothing' (1:4). In this way James brings his thought to his intended climax. Effectively, James is saying: 'Let steadfast endurance make you perfect' (Dibelius 1975: 74). The notion of perfection required the idea of wisdom in the underlying wisdom tradition: 'For even one who is perfect among human beings will be regarded as nothing without the wisdom that comes from you' (Wis 9:6). For this reason James 1:2-4 is incomplete in that perfection demands a reference to the possession of wisdom. This is supplied by 1:5-8. Because wisdom is God's gift enabling one to stand the test, it is to be sought in prayer from God with firm confidence. This is a clear illustration of the gospel tradition of 'ask and it will be given you' (Luke 11:9).

\subsubsection{The wisdom from above (3:13-18)}

Elsewhere, I argued that this is the central pericope in the epistle, the other pericopes forming an embrace around it (Hartin 1991:29-32). This passage contains the most direct reflection on wisdom. A striking connection with the previous pericope (3:1$12)^{2}$ appears through the parallelism in the opening of each pericope: 3:1 deals with

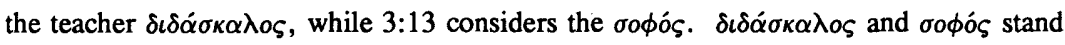
in parallel fashion to each other. Both pericopes show concern with divisions within their ranks. In a sense teachers can be held responsible for starting or fuelling these 
disputes (3:1). At the same time in discussing the nature of wisdom James acknowledges that selfish ambition is the chief obstacle to obtaining wisdom. The teacher is the wise person: the $\delta i \delta \alpha \sigma \alpha \alpha \lambda \circ \varsigma$ becomes the $\sigma o \phi o ́ \varsigma$. Mussner (1981:168-169) shows that this shift from $\delta \delta \delta \alpha \sigma \kappa \alpha \lambda$ s to $\sigma 0 \phi o ́ \varsigma$ reflects the world of the first century CE where the two concepts were being used interchangeably. As Mussner (1981:168-169) says: 'Weil im Spätjudentum der Lehrer (Rabbi) und der Weise fast identisch sind.' The focus centers upon the wisdom from above. As I have examined this passage in detail elsewhere (Hartin (1991:97-113), here I wish to highlight some of the aspects of this investigation that have significance for this study. This section unfolds in a threefold way:

First, James 3:13 presents the criterion for true wisdom and asks the question: 'Who is wise and understanding?' While the phrase 'wise and understanding' (бoфòs $\kappa \alpha i \dot{\varepsilon} \pi \iota \sigma \tau \dot{\eta} \mu \omega \nu)$ does not occur in the rest of the New Testament, it is found frequently in the Septuagint (Davids 1982:150; for example, Deut 1:13; 4:6; Sir 21:15; and Dan 1:4). James argues that whoever makes a claim to be a leader in the church ( $\delta\llcorner\delta \alpha \dot{\alpha} \sigma \alpha \lambda \lambda o \varsigma$ - $\sigma o \phi o ́ \varsigma)$ must lead a life that demonstrates faith in action. In addition to

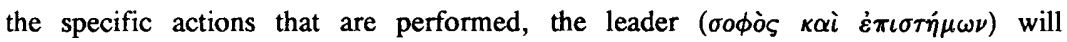

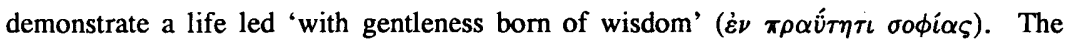
believer is challenged to see the cardinal virtue for life as consisting in 'meekness' (especially in situations of strife) (Davids 1982:150). This is a characteristic Christian virtue as can be seen from its appearance in almost every tradition of the New Testament (Gal 6:1; Eph 4:2; 2 Tim 2:25; Tit 3:2; 1 Pet 3:16; James 1:21). For James the truly wise person (the true leader) is one whose life and actions are directed by the virtue of meekness. This sentence operates as a topic sentence for the rest of the vices and virtues that follow and it acts as a guiding force for each list. There is a striking parallel to this verse in Sirach 3:17: 'My child, perform your tasks with humility; then you will be loved by those whom God accepts.' Again James demonstrates that he lies close to the wisdom world view of Sirach which sees one's life directed by virtues such as meekness.

Secondly, James 3:14-16 gives a negative definition of a lifestyle led without wisdom. In this and the next section James contrasts two lifestyles: one led without wisdom (3:14-16) and one led with wisdom (3:17-18). The proper lifestyle of one who is

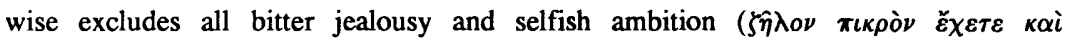
$\dot{\varepsilon} \rho(\theta \varepsilon i \alpha \nu)$. James calls upon those who are filled with contentiousness to refrain from claiming inspiration from God's wisdom. They cannot possess God's wisdom if at the same time they are full of jealousy and cause dissensions. As Dibelius (1975:210) 
states: 'The boast which defies the truth is their claim of wisdom, for true wisdom cannot be contentious to be honest and to cease claiming inspiration from God's wisdom.' On a number of occasions James teaches that true wisdom comes down from heaven (James 1:5; 1:17 and 3:17). In the Jewish wisdom tradition it was tantamount to an axiom that all true wisdom is divine in origin and comes down from heaven ( $\mathrm{Pr}$ $2: 6$; 8:22-31; Sir 1:1-4; 24:1-12; Wis 7:24-27; 9:4, 6, 9-18).

Finally, James 3:17-18 presents a positive definition of wisdom in describing the true wisdom from above ( $\alpha \nu \omega \theta \varepsilon \nu \sigma o \phi i \alpha)$. James 1:17-19 helps to shed light upon the understanding of this text. 'Every generous act of giving, with every perfect gift, is from above, coming down from the Father of lights, with whom there is no variation or shadow due to change' (James 1:17). In this context wisdom is the great gift that comes down from above (Davids 1982:88). This gift from above, this wisdom, results in the person receiving the word of truth ( $\lambda$ ó $^{\prime}{ }^{\circ} \dot{\alpha} \lambda \eta \theta \varepsilon i \alpha \varsigma$ ) and becoming 'a kind of first fruits of his creatures' (1:18). From the context it appears as a reference to Jewish-Christians as the first to be reborn in God's process of redemption. (Davids 1982:89; Dibelius 1975:104-105; Mussner 1981:94-94; Adamson 1976:76-77).

The gift of God from above, of which the greatest is wisdom, results in a rebirth. 'The word of truth' ( $\left.\lambda \operatorname{co\gamma o\varsigma }^{\alpha} \lambda \eta \theta \varepsilon i \alpha \varsigma\right)(1: 18)$ is referred to in $1: 21$ as the $\check{\varepsilon} \mu \phi v \tau o \varsigma$ $\lambda o ́ \gamma o \varsigma$. Although the meaning of $\check{\varepsilon} \mu \phi v \tau o \zeta$ has been variously interpreted as inborn, innate, natural, the more commonly accepted translation is that of 'implanted.' (Dibelius 1975:113; Davids 1982:95; Adamson 1976:98-100; Johnson 1995:202). This.implanting takes place through the proclamation of the Gospel. As Davids (1982:95) says: 'Thus the God who regenerates (begets) the Christian by the word of truth, will save him by the same word implanted in him if he receives it.' With this as the wider context to $3: 17$ the wisdom from above appears not simply as a gift directed to a specific moral type of life, but as bringing with it regeneration and rebirth. The eschatological is already seen to have begun in that believers are promised the gift of wisdom that works in them a regeneration and makes of them 'first fruits'. The audience to whom James writes already now participate in the eschatological age announced by the prophets of old.

The promise of the fruit of righteousness for those who work for peace $(3: 18)$ is part of the promise of the wisdom that is from above. This promise occurs in an eschatological perspective (Hoppe 1977:67). All the ethical admonitions in this section are directed towards this eschatological gift of righteousness. The one who has lived by the qualities of wisdom will possess the fullness of the gift of righteousness in the life to come. 


\subsubsection{Significance of this investigation}

James lies clearly within the wisdom tradition emanating from the Old Testament and the intertestamental writings whereby all true wisdom comes from above. In his reflection on the nature of wisdom James has emphasized the following aspects:

* It comes down from above from God;

* it is communicated to people as a result of their requests;

* it brings with it the necessary virtues for leading a specific way of life; and

* above all it works rebirth and regeneration in the heart of the believer who becomes 'a kind of first fruits of God's creatures' (1:18).

Characteristic of James' application of the wisdom tradition is the fact that he has broadened the perspective to incorporate consistently an eschatological perspective. Attention will now be given to the significance of this focus upon the eschatological to identify the purpose and effect that his broadening of the wisdom tradition had in the context of the Epistle of James.

\subsection{The function of the eschatological in the Epistle of James}

Eschatology provides the context for the teaching of this writing. Because James shares a common world view with his readers, he does not need to give a detailed explanation or description of this thought world. Instead, he presupposes it. Davids (1982:39) goes on to argue that one can presume from this that James's readers must have had a certain apocalyptic understanding: 'This community, like Paul's (cf. 2 Thessalonians 2), has seen to it that the apocalyptic teaching is among the basics of the faith. Without an appreciation of the foundational role this teaching played in the Christian world view of James's church, one could hardly understand the joy referred to in 1:2,12. This is, as J. Thomas has aptly put it, 'eschatologische Vorfreude,' anticipated joy in the face of trials because of the reward which one knows is fast approaching'.

\subsubsection{The present acts as the beginning of the end time}

\subsubsection{1 'To the twelve tribes in the dispersion' (1:1)}

The epistle opens with the address: 'To the twelve tribes of the Dispersion' (1:1). The exact meaning is greatly disputed. (See, for example, the different perspectives adopted by Dibelius [1975:66-68]; Laws [1980:47-49]; Müssner [1981:11-12]; Davids [1982:63-64]; and Johnson [1995:169]). I think the best approach is to understand it in 
the context of the hope in the restoration of the twelve tribe kingdom of Israel. Nathan, the prophet, promised King David that his kingdom would not end: 'Your house and your kingdom shall be made sure forever before me; your throne shall be established forever' (2 Sam 7:16). The belief arose that the twelve tribe kingdom would continue for ever. This belief survived despite the destruction of both the northern and southern parts of the land of Israel. During the exile the prophets began to proclaim the return of the people and the restoration of the destroyed twelve tribe kingdom (for example, Ezekiel 37:19-24; Jeremiah 3:18; Sir 36:13 [MT]). This became a central conviction of Jewish eschatology and apocalyptic literature. The literature specific to the Qumran community also presupposes the restoration of the twelve tribe kingdom. It even plans the organization of the Qumran community, its battle order and the Temple, as if it were already a fact.

This belief in the coming of the kingdom provided the motive for John the Baptist's call to repentance: 'In those days, John the Baptist appeared in the wilderness of Judea proclaiming, 'Repent, for the kingdom of heaven has come near' (Mt 3:1-2). In the context of the ever intensifying kingdom eschatology, the first generation Judean Church must have held similar views to those expressed by John. They, as well as John, were preparing the people for the dawn of a restored twelve tribe kingdom. It is for this purpose that the Gospel writers present Jesus appointing a group of twelve.

In the tradition of the Gospel of Matthew the importance of the twelve tribes emerges even more forcefully. Jesus has the exclusive task of reconstituting the twelve tribes of Israel. In Matthew 15:24 Jesus counters the shouting of the woman from Tyre and Sidon with the statement: 'I was sent only to the lost sheep of the house of Israel.' This passage conveys the belief that the Matthean community saw the gathering-in of the lost sheep of the house of Israel as a task of Jesus. When Jesus in turn commissioned the Twelve, he was in effect delegating this same task to them, namely, of gathering together the lost tribes.

The full eschatological understanding of the twelve tribes emerges in the final saying of the Sayings Gospel Q: 'And I confer on you, just as my Father has conferred on me, a kingdom, so that you may eat and drink at my table in my kingdom, and you will sit on thrones judging the twelve tribes of Israel ' (Lk 22:24-30//Mt 19:27-29): In this instance a future role is attributed to the twelve disciples, a role that shares in the role of the Son of Man and involves judging the twelve tribes: a task that includes the gathering-in of those who truly belong to the twelve tribes at the end of time.

In addressing his readers in this way, James is exercising the role of gathering-in the twelve tribes of Israel. James sees these Jewish Christians now as the true Israel for whose restoration the Jewish nation had been hoping for centuries. Now this hope is 
being realized. So the eschatological hope of Israel's past reaches fulfillment. The beginning of the end time occurs with this Jewish-Christian community which is the twelve-tribe people ${ }^{3}$.

\subsubsection{2 'The first fruits of his creatures' (1:18)}

Those who belong to this new Israel, the twelve tribes, are 'the first fruits'. The language and thought of creation permeate both this verse and the preceding one. Without doubt James has in mind the eschatological creation in which Jewish Christians are consciously conceived of as the first fruits $(\dot{\alpha} \pi \alpha \rho \chi \dot{\eta})$ of God's creatures. Here, we are in the context of creation, but creation conceived of as redemption, as a new creation. God's redemptive activity results in Jewish Christians becoming the first-fruits of God's creatures $(\kappa \tau \iota \sigma \mu \alpha \tau \omega \nu)$. The word $\kappa \tau i \sigma \mu \alpha$ is often used in the wisdom literature to refer to God's creatures (e.g. Wis $9: 2 ; 13: 5 ; 14: 11$; Sir 36:20). James $1: 17$ referred to the 'Father of Lights,' which also has the creation in mind: God is the creator of the sun and moon. Genesis 1:14-15 speaks of the lights of the heavens: 'Let there be lights in the dome of the sky to separate the day from the night; and let them be for signs and for seasons and for days and years, and let them be lights in the dome of the sky to give light upon earth.' A similar expression to $\pi \alpha \tau \grave{\eta} \rho \tau \hat{\omega} \nu \phi \dot{\omega} \tau \omega \nu$ appears in the Armenian translation of the Apocalypse of Moses 36:38; in Job 38:28 there is reference

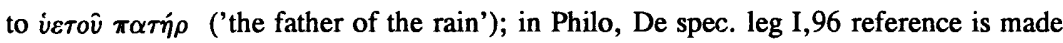
to the 'father of the kosmos' ( $\tau \hat{\omega} \tau o \hat{v}$ кó $\mu \rho \nu \pi \alpha \tau \rho \hat{\imath})$ : and in the Testament of Abraham

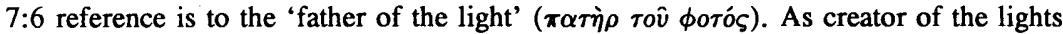
of heaven, God is different from creatures in that in God there is no variation: 'In him there is no variation or shadow due to change' $(1: 17)$.

While using terminology related to creation, James has in mind the new creation which brings about a rebirth. The starting point for God's new creative activity lies with Jewish-Christians, but it is not intended to end there. It is meant to embrace ultimately all humanity (Mussner 1981:96). The 'first-fruits' implies that others will follow. Once again the eschatological world view is basic to the understanding of the entire epistle. Addressed to those who are the first-fruits of this eschatological age, the epistle also looks forward to a future where this will be brought to fulfillment. Creation imagery is used to give further understanding to this eschatology.

\subsubsection{The present acts as the preparation for the end time}

The present is on the threshold of the end of history. The new age has begun to break in and that brings with it a tension between this world and the world that is ultimately 
to come (Davids 1982:38). James 5:7-11 captures this eschatological tension between the present and the future. This passage is rich in traditional eschatological images: the

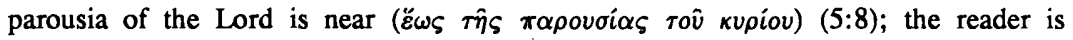
exhorted to have patience in this intervening period before the coming of the Lord, which will usher in a period of judgment, for the 'Judge is standing at the doors!' (5:9). The images of 'the coming of the Lord' and the 'Judge' are ones that belong to the eschatological world view.

The context of this passage focuses especially upon the judgment of the rich who have not recognized the imminent judgment. James 5:1-6 condemns the rich in true prophetic fashion for the way in which they have behaved: they 'have laid up treasure for the last days' (5:3); they have amassed fortunes and have behaved as if they will last for ever; they have not realized that the 'last days' have already broken upon the world; they have 'fattened (their) hearts in a day of slaughter' $(5: 5)^{4}$. Their actions have made them ready for the day of God's judgment.

This is the closest that James comes to the use of apocalyptic language. He uses it without emphasis and does not develop the descriptions that are so characteristic of apocalyptic. In the same context (5:17) James refers to another symbol that appears in the eschatological world view: namely, Elijah. According to the tradition Elijah is due to return before the end of the world. Thus Elijah prepares the people of God for the last time' (Jeremias 1964:934). However, James focuses not on the eschatological, but on Elijah as a 'human being like us' (5:17). The biblical picture had showed Elijah as a man of prayer, a man whose prayer had powerful effects (1 Kings 18:36-40): it is to this James draws attention. James turns away from apocalyptic speculations to focus upon a human quality that speaks more vividly to his readers.

The awaited 'coming of the Lord' brings both judgment and salvation: judgment against those who have failed to follow the right path (chief among these are the rich); and salvation for those who are patient (chief among these are the poor). The themes of judgment and salvation run like threads throughout the letter. Negatively, the theme of judgment sees the rich fading away like the flowers in the field (1:10); in the middle of life they wither away (1:11). Positively, this letter promises a 'crown of life' $(1: 12)$ for those who love God. It promises as well to those who are poor that they will be 'heirs of the kingdom' (2:5). Finally, those who are sick acquire the eschatological gift of the forgiveness of sins (5:15). In effect the Epistle of James shows that the whole life of the believer is orientated towards a future with an eschatological end resulting in either salvation (life) or judgment (condemnation). 


\subsubsection{Eschatology and ethics}

James has used the eschatological perspective as the motivation for his wisdom advice: perfection is the ultimate aim towards which all ethical action is directed, a perfection that is attained only at the 'coming of the Lord.' Throughout the letter James issues a call to perfection. He opens the letter with the call: 'let endurance have its full effect ( $\tau \dot{\varepsilon} \lambda \varepsilon \iota \nu \nu)$, so that you may be mature ( $\tau \varepsilon \lambda \varepsilon \iota 0 \iota)$ and complete, lacking in nothing' (1:4). The perfection to which James calls his readers is not a perfection that is acquired in the Stoic way of 'natural' perfection, worked by one's own actions (Mussner 1981:210). Instead, it is to be viewed in the eschatological sense in that it is something that only comes to fullness in the future. One's life in the present is meant to be led in such a way that one aims toward that perfection. For this reason all the ethical instructions within the letter are embraced by the eschatological. It has been described as an 'Interimsethik' (Mussner 1981:210) - a way of life for the present which is on its way to fulfillment in the fullness of the eschatological age.

On the negative side judgment acts as a caution. The teacher is warned: 'for you know that we who teach will be judged with greater strictness' $(3: 1)$. Believers are cautioned against acting as a judge of one's neighbor in the present, because this will fuel their own judgment in the future: 'There is one lawgiver and judge who is able to save and to destroy. So who, then, are you to judge your neighbor?' (4:12). The correct use of the tongue is also stressed (3:5-10), as is the correct usage of the taking of oaths 'that you may not fall under condemnation' (5:12).

On the positive side the eschatological motivation provides certain promises:

* Those who withstand temptation are promised 'the crown of life' (1:12).

* Those who persevere 'will be blessed in their doing' (1:25).

* Those who put faith into action, who pioduce a faith that is alive, will be justified: 'You see a person is justified by works and not by faith alone' (2:24).

* Those who bring back 'a sinner from wandering will save the sinner's soul from death and will cover a multitude of sins' $(5: 20)$.

* Those who are 'the poor in the world...' will be 'heirs of the kingdom that he has promised to those who love him' (2:5).

* Part of the eschatological context of the ethical admonitions is that it provides an encouragement to patient endurance: 'Be patient, therefore, beloved, until the coming of the Lord' (5:7). James links encouragement to endure with eschatological hope. 


\subsubsection{An apocalyptic eschatology?}

In encouraging people to persevere amidst trials and temptations (1:12) James does not give any detailed description of what the trials actually are, as tends to occur in the graphic descriptions that traditional apocalyptic imagination gives to the sufferings and persecutions of the righteous (Laws 1980:28). James is far more restrained. The trials and sufferings he has in mind are the more ordinary or daily ones. As Laws (1980:28) says: 'James gives no indication in 1.2 of the nature of the 'various kinds of trials' to be encountered, but his examples of endurance of v.7, the farmer, and v.11, Job, suggest that he thinks of the everyday difficulties facing the individual rather than of a particular crisis...'

For example, James 1:27 refers to the affliction of widows and orphans by using the term $\theta \lambda i \psi(\varsigma$ (affliction). This is a technical term occurring in apocalyptic literature for the sufferings of the eschatological age. Schlier (1972:139-148) argued that this term in the Septuagint had acquired a 'theological significance from the fact that it predominantly denotes the oppression and affliction of the people of Israel or of the righteous who represent Israel' (1972:142). In the New Testament the same term is adopted with theological significance to refer to sufferings now endured by the Christian church in the eschatological age: 'If we thus see that it belongs to the nature of $\theta \lambda \hat{i} \psi(\varsigma$ in the NT, first, that it is inseparable from Christian life in this world, and secondly, that it is the suffering of Christ, who is afflicted in His members, a third characteristic is that this is eschatological tribulation' (1972:144). Attention is drawn in the New Testament usage of this term especially to the sufferings that occur prior to the parousia (Mt 24:21 speaks of the sufferings of the disciples prior to the end). The Book of Revelation sees the sufferings and tribulations of the present as already being experienced and marking the beginning of the end: 'E $\gamma \omega$ ' $^{\prime} \omega \dot{\alpha} \nu \nu \eta \zeta, \dot{o} \dot{\alpha} \delta \varepsilon \lambda \phi \grave{o} \varsigma \dot{\nu} \mu \hat{\omega} \nu$

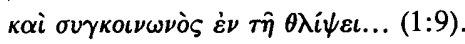

It is against this background that the usage of $\theta \lambda \hat{\imath} \psi \iota \varsigma$ in James is to be understood. Most commentators ignore this background to this usage in James (for example, Johnson [1995:212] who says: 'There is no need to look beyond the chronic condition of the orphans and widows for a suitable definition of thlipsis.' Laws (1980:28), however, draws attention to this usage of $\theta \lambda i \psi(\varsigma$. She later (1980:89) adds: '...elsewhere in the NT the noun thlipsis has almost the status of a technical term for the sufferings that precede the End, the 'Messianic Woes', e.g. Mk xiii.19; 2 Thess i.4; Rev. ii.22; cf Dan xii.1; Hermas, Vis.ii.2.7. In Col.i.24 Paul seems to see his own sufferings as contributing to the thlipseis tou Christou, the 'Messiah's affliction' which his people must bear.' 
James, however, does not focus upon its possible apocalyptic setting. Instead he places it within the context of the sufferings of the widow and the orphan. Why is there this change? It appears to be a deliberate reinterpretation of the tradition in order to show that the present events are indeed signs of the coming end. James reinterprets the everyday sufferings of those most abandoned in society as the signs that the end is rapidly approaching. Laws (1980:90) examines the reason for this shift in the usage of the term thlipsis and she concludes to two possible reasons for this change: 'It could be that he is trying to dispense with the old eschatological ideas, finding them no longer appropriate.... Alternatively James may be trying to keep the expectation alive and real in a situation where the traditional 'signs' are conspicuously lacking, and in that attempt he carries out a deliberate re-interpretation of the nature of the signs.'

Eschatology is essential to the Epistle of James for it makes of the letter more than just a collection of paraenetical wisdom sayings, as Dibelius was want to categorize it (Dibelius 1975:3-4). It is my contention that James is aware of the apocalyptic imagination - it is part of the thought patterns that he shares with his contemporaries and in particular with his readers. However, James tends to distance himself from this imagination for two reasons: First of all, the usual apocalyptic signs of the end are missing. James is convinced that the eschatological age is upon them with the 'Judge standing at the doors!' (5:9); however, those elements that belong to a truly apocalyptic era are absent. This leads James to a reinterpretation of the apocalyptic signs. The ordinary sufferings of the present are reinterpreted as signs of the end - such as the tribulations afforded the widow and orphan, as well as the trials faced by every brother and sister: 'My brothers and sisters, whenever you face trials of any kind, consider it nothing but joy' $(1: 2)$.

Secondly, despite the view that the coming age does bring with it judgment, the ethos of the whole epistle is that this coming age is to be approached not with fear and trepidation, but with joy and happiness as the letter itself opens: 'Count is all joy'

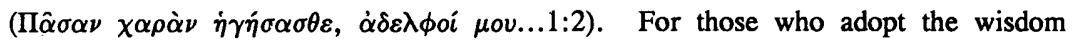
exhortations of James there is hope, joy, peace and perfection - with nothing to fear. The traditional apocalyptic description of the destruction of the wicked is absent from James - in its place stands the positive challenge that the writer lays before his readers to endure amidst the sufferings and persecutions of this age. The focus rests on the future hope: 'the Lord of glory' (2:1) who provides the 'crown of life' (1:12), rather than on dread and fear of judgment. 


\section{THE EPISTLE OF ENOCH AND THE EPISTLE OF JAMES}

The Epistle of Enoch (1 Enoch 92-105) $)^{5}$ bears a number of similarities to the Epistle of James. An examination of these similarities may help to further specify the character of the Epistle of James in so far as it relates to the traditions of wisdom, prophecy, eschatology and apocalyptic. The following characteristics may be observed:

First, the Epistle of Enoch is presented as a letter that is addressed from the ancient 'patriarch' Enoch to 'all the offspring that dwell upon the earth, and for the latter generations which uphold uprightness and peace' (1 Enoch 92:1) ${ }^{6}$. This bears a counterpoint to the Epistle of James, which as a letter is addressed from James, a 'patriarch' in early Christianity, to 'the twelve tribes in the dispersion'. In a sense the addressees are analogous: while Enoch is addressed to all his spiritual descendants throughout time and the world (Nickelsburg 1992:511), James is addressed to Jewish Christians, the spiritual descendants of Israel throughout the world. In effect the intention is the same: to offer advice on how to lead their lives.

Secondly, throughout both epistles lies the contrast between the righteous and sinners and the respective judgments that await them in the future. 'Now, my children, I say to you: Love righteousness and walk therein! For the ways of righteousness are worthy of being embraced; (but) the ways of wickedness shall soon perish and diminish' (1 Enoch 94:1). Likewise James states: 'You do well if you really fulfill the royal law according to the scripture, 'You shall love your neighbor as yourself.' But if you show partiality, commit sin and are convicted by the law as transgressors...' (James 2:8-9). However, while in James there is reference to judgment, there is no detailed description of the judgment as occurs in 1 Enoch (92-105).

Thirdly, the major similarity between 1 Enoch (92-105) and the Epistle of James is that they both employ many of the same literary forms in their composition. Nickelsburg (1981:146) has shown that 1 Enoch (92-105) uses three major literary forms throughout: 'This central part of the epistle is comprised almost entirely of three literary forms well known from the biblical tradition, especially from the prophets.' I refer to those literary forms identified by Nickelsburg in order to compare the Epistle of James in this regard.

\subsection{Woes}

The form of woes presents the charge of evil against sinners as well as the impending judgment they can expect. For example: 
Woe unto those who build oppression and injustice!

Who lay foundations for deceit.

They shall soon be demolished.

(1 Enoch 94:6)

While some of the woes are directed against those who abandon the teachings of the Torah, the majority concerns those who fail in social demands (Nickelsburg 1981:147). A particular concern is expressed for the way in which the rich abuse the poor.

The occurrence of the woe is not as marked in the Epistle of James as it is in 1 Enoch (92-105). As has already been indicated, the Epistle of James contains only two 'woes' (James 4:13-17; 5:1-6). James's concern is largely of a social nature and in particular with the way the rich have mistreated the poor. Judgment and destruction also await them in the future. In the condemnation of the rich James and 1 Enoch (92105) share some close similarities. James $5: 5$ condemns the rich for having 'fattened your hearts in a day of slaughter.' 1 Enoch uses a similar image: 'Woe unto you, $O$ rich people... In the days of your affluence, you committed oppression, you have become ready for death, and for the day of darkness and the day of great judgment' (1 Enoch 94:8-9). For the rich are guilty of oppressing the poor, who are identified as the 'righteous' (James 5:6; 1 Enoch 96:7-8). A divine punishment will ultimately be carried out against the rich.

\subsection{Exhortations}

These express a call to the righteous to persevere in the life of courage and peace that they are leading:

Be hopeful, you righteous ones, for the sinners shall soon perish from before your presence.

You shall be given authority upon them, such (authority) as you may wish to have.

(1 Enoch 96:1)

The Epistle of James is essentially a series of admonitions and advice on how to lead one's life. While the material in James in largely composed of exhortations, 1 Enoch (92-105) contains far more woes than exhortations. 


\subsection{Descriptions of judgment}

In 1 Enoch (92-105) passages of judgment are generally introduced by expressions such as 'In those days' and they show their similarity to the prophets (Nickelsburg 1981:148). For example:

In those days, the prayers of the righteous ones shall reach unto the Lord; but for all of you, your days shall arrive.

He shall read aloud regarding every aspect of your mischief, in the presence of the Great Holy One.

Then your faces shall be covered with shame, and he will cast out every deed which is built upon oppression.

(1 Enoch 97:5-6)

James on the other hand does not enter into descriptions of judgment. Instead the epistle is content with focusing on the present and issuing warnings to sinners, rather than giving detailed descriptions of what punishments lie ahead. Here James seems to lie closer to the wisdom tradition where forms of comparison dominate.

The above examination shows that both Enoch ${ }^{7}$ and James use traditional material that is at home both in the prophetic and in the wisdom traditions, yet they use them in different ways and in different degrees. Woes and admonitions/exhortations occur in both traditions, as is evidenced in Ben Sirach $(2: 12-14 ; 41: 8)$ as well as the prophets. 1 Enoch 92-105 gave more emphasis to the woes, while James made more use of the form of the exhortation and admonitions. Both demonstrate that a clear distinction between prophetic and wisdom traditions at the time of composition of these texts was non existent (Nickelsburg 1977:327). In effect for Enoch (92-105) the wise and the righteous are identical. For example, 1 Enoch 104:12 'Again know another mystery!: that to the righteous and the wise shall be given the Scriptures of joy, for truth and great wisdom.' James too is interested in calling his readers to become wise: 'Who is wise and understanding among you?' (James 3:13). For James the wise and the teacher are identical.

However, the major difference between the Epistle of Enoch and the Epistle of James lies in the focus that Enoch places upon the revelation of the future that acts as a comfort for those suffering now. The imminent future day of judgment is the revealed message that Enoch (92-105) communicates to his readers, a day that will overcome 
injustice and bring the righteous to happiness (1 Enoch 102:1; 103:1-3). This revealed message shines through both the prophetic and wisdom traditions used by Enoch and in turn brings Enoch into the orbit of the apocalyptic genre. It is especially the claim to the revelation of the heavenly realm and the future that produces its apocalyptic connections (1 Enoch 97:6). The apocalyptic genre becomes more obvious from the context in which 1 Enoch 92-105 occurs: the Apocalypse of Weeks (93:1-10; 91:11-17) appears within this section (92-105), while the visions of the other world in chapters 136 provide further justification for the revelatory message that Enoch proclaims. As Nickelsburg (1981:149) says: 'The epistle of Enoch is similar to other apocalyptic writings in the kind of situation it presumes, the message it conveys, and the purpose for which it was written. The author exhorts his readers to steadfastness on the basis of a revealed message about an imminent judgment that will remove oppression and adjudicate injustice. This work shares with the apocalypses we have treated the claim that it is an ancient writing intended for latter-day readers. It differs from them in form. Although it contains a brief, sketchy apocalypse, as a whole it is not an ordered account of events to come.'

Nickelsburg (1977:326) describes the genre of 1 Enoch 92-105 in this way:

Wherein does Enoch 92-105 cohere? How does the author perceive reality, and indeed his writing, within that context? I should express the message pervading the whole of these chapters as follows:

The revelation of God's unseen world and future paradoxically calls the oppressed community to faith, courage, and joy in the present.

The centrality of revelation to these chapters makes the adjective 'apocalyptic' altogether appropriate as a description of the author's message.

(Nickelsburg 1977:326)

Not having the wider context that 1 Enoch $92-105$ is able to embrace, the Epistle of James does not contain the strong descriptive revelation of the future judgment (as Enoch has) that gives meaning to the present. Belief in a future judgment operates in James as an explanation for the way in which one should conduct one's life now in the immediate expectation of the 'coming of the Lord.' James 5:1-11 provides the future climax which gives meaning to the present. However, in comparing the reference to judgment in James and 1 Enoch 92-105, what is notable is that in James no description is given to this future judgment that will befall the righteous and the sinner (as occurs in Enoch). 
This examination of 1 Enoch (92-105) is most helpful in throwing light upon the nature of the Epistle of James. The most noteworthy difference is that revelation, so central to 1 Enoch, is absent from the Epistle of James. It is precisely this aspect of 'revelatory literature' that separates the Epistle of James from the apocalyptic genre. The definition of the genre of an apocalypse, as given by Collins (1992:4), is worth noting as further support for showing that James does not conform to the genre of an apocalypse: 'An apocalypse is defined as: a genre of revelatory literature with a narrative framework, in which a revelation is mediated by an otherworldly being to a human recipient, disclosing a transcendent reality which is both temporal, insofar as it envisages eschatological salvation, and spatial insofar as it involves another, supernatural world.'

While universal agreement is far from having being achieved in providing a definition of 'apocalyptic genre', there are some aspects that are seen as vital in establishing such a definition. It is judged to belong to that wider category of writing, known as revelatory writing (Hellholm 1991:146; Collins 1991:11-12). Collins (1991:19) further clarifies his definition when he says: 'I would now accept the amendment to the definition of the genre offered in Semeia 36, in the light of the suggestions of Hellholm and Aune: an apocalypse is 'intended to interpret present earthly circumstances in the light of the supernatural world and of the future, and to influence both the understanding and the behavior of the audience by means of divine authority.'

Essential to this definition is the notion that 'revelation' is the distinguishing mark of this type of writing. According to this perspective, then, the Epistle of James does not belong to this category. It has no concern with a revelation of the future or the heavenly world; its attention is directed specifically to the present. There is no narrative framework given to the epistie, neither is their any supernatural being present that mediates the transcendent world.

This is not to deny that the future does operate in James as a call to the present. To paraphrase Nickelsburg (1977:326) one can say: 'In the Epistle of James the future calls the oppressed community to faith, courage and joy in the present.' However, there is no 'revelation of God's unseen world' as there is in Enoch. The coming of the Lord is imminent, but there is no description of that coming, nor of what the world will be like after that coming. It is presented as an event in the immediate future, but James does not speculate on it, nor does he give information about it. While the context of the audience of James does include situations of oppression and affliction, the exhortations and wisdom comparisons give a picture of a community that needs to be reminded of the importance of putting faith into action, of fulfilling the law of love, of bridling the tongue, and so forth. 
On the other hand one cannot claim that James is generically pure. While the imagery of Daniel or Revelation is lacking in James, nevertheless the world of James is a world that is dominated by evil to the extent that James defines religion as keeping oneself 'unstained by the world' (1:27). The future does operate as the motivation for the way one leads one's life in the present. The future proclaims the imminent coming of the Lord, as the 'Judge standing at the doors!' (5:9).

Because revelation does not function in the Epistle of James in the same was as it does in the Epistle of Enoch, and because any imagery or language of apocalyptic in James is relatively low key, James cannot be classified as an apocalypse. While James bears some characteristics in common with the Epistle of Enoch, this aspect of revelation provides the dividing line separating James from 'apocalyptic'. In this way the Epistle of Enoch has helped to give further clarity about the nature of the Epistle of James and its relations to the wisdom, prophetic, eschatological and apocalyptic traditions.

\section{CONCLUSION}

\subsection{Genre and traditions}

The Epistle of James belongs to that wisdom tradition that offers practical advice and instruction on the art of leading one's life. Two aspects of wisdom material are evident, namely wisdom instruction or exhortations and reflection upon wisdom, upon its origin with God. This corresponds to the first two categories of wisdom material that Collins (1993:168) identifies within Israelite traditions, namely wisdom sayings and theological wisdom. The other three categories, namely nature wisdom, mantic wisdom and higher wisdom through revelation, are absent from the Epistle of James. The issue of genre shows that the nature of the Epistle of James is wider than just one category. Both the prophetic and eschatological play a decided influence in determining the nature of the Epistle of James. Prophetic forms are used in order to give expression to the wisdom advice. At the same time eschatology plays a vital role in providing motivation for the wisdom teaching that is offered. This is different from the traditional wisdom of the Old Testament and intertestamental periods. For James the future holds sway over the present. The coming of the Lord acts as the motivation for the way one leads one's life in the present: it gives meaning to all the ethical advice.

In line with the Epistle of Enoch (92-105) James demonstrated a usage of similar traditional material: such as prophetic woes and admonitions. Eschatology also played a dominant role in each text by providing the motivation for the present: James and Enoch are heirs to traditions which they used in different ways. In 1 Enoch (92-105) 
the apocalyptic revelatory genre unites the wisdom, prophetical and eschatological material together. In James, on the other hand, wisdom provides the unifying force in bringing together the prophetical, and the eschatological material, while distancing itself from the apocalyptic.

\subsection{World view}

The revelation of the future is not a focus for the writer of the Epistle of James, as it is with apocalyptic texts. As Nickelsburg (1994:722) says: 'The authors of apocalyptic texts, while they actually draw heavily on the Torah and the prophets, present new revelations, although they attribute them variously to pre-Mosaic authors (Enoch and Abraham), Moses himself, and post-Mosaic figures (Daniel, Ezra and Baruch). The sources of these new revelations are said to be cosmic journeys and dream visions, interpreted by angels.' Neither is James couched in dreams, visions or revelations by means of angels. However, James does seem to share aspects of some thought patterns present in an apocalyptic world view: he knows of the world of devils (2:19); that the world of future judgment brings about a separation between the righteous and the sinner (5:1-11); and that there is a 'crown of life' (1:12) in store for those who show their love of God. While James shares these thought patterns with his contemporaries, they do not displace his focus of providing exhortations and advice to the readers about how they are to lead their lives in the present. James does not work out a comprehensive world view whereby this world is understood only in relation to the heavenly world. In this sense, then, James is not apocalyptic.

Reflection on the Torah, so characteristic of the wisdom writings of the Old Testament as well as the intertestamental periods, has continued in the Epistle of James. Certainly the Torah provided the foundation against which one can judge the practical advice that is given for the way to lead one's life. The Epistle of James has given this reflection on the Torah a particular focus with a centrality assigned to the law of love: 'You shall love your neighbor as yourself' (identified as well as the 'royal law' (2:8), and 'the law of liberty' [2:12]). This law of love provides impetus for the ethical advice that becomes a specific illustration of this law in action, whether it be "caring for widows and orphans'; or showing no partiality with regard to rich and poor (2:1-7); or even the bridling of one's tongue (3:5-10).

\subsection{Community}

The community presupposed by the Epistle of James is the wider Jewish-Christian community outside Palestine ('the twelve tribes in the Dispersion' 1:1). In the very desig- 
nation, 'the twelve tribes in the Dispersion,' the author reminds the readers of their eschatological position in the plan of God. They are the reconstituted people of Israel expected in the eschatological age.

Despite its distinctiveness, the community nevertheless remains an open community: outsiders are welcome, as seen by the entry of a rich person into the community. (2:1-13). James challenges the members of the community to make everyone welcome, not just the rich. The community shows an obligation of caring for its own members: the suffering, the ill (5:13), and in particular the sinner who 'wander from the truth' (5:19).

While the community which the epistle envisages does experience sufferings and persecutions, these emanate chiefly from the hands of the rich against the poor. The sufferings are not the apocalyptic cataclysmic destructions of Revelation and Daniel. Yet, the same technical language is used to refer to the sufferings and afflictions of the present moment, such as those endured by widows and orphans ( $\theta \lambda i \hat{\imath} \iota \varsigma, 1: 27)$. Tensions emerge within the community when it discriminates against the poor in favor of the rich (2:1-12). The community gathers together as an assembly ('the synagogue' [2:2]). Certain structures are also evident within the epistle which show a remarkably early period: the sick are invited to call upon 'the elders of the church' $(5: 14)$. The writer is a teacher ('for you know that we who teach...' [3:1]), who strives after wisdom: 'Who is wise among you' (3:13). The categories of $\delta \iota \delta \dot{\alpha} \sigma \alpha \alpha \lambda \circ \varsigma$ and $\sigma o ́ \phi o \varsigma$ are identical. As a wisdom teacher James aims at transmitting, not knowledge, but ethical exhortations in line with the way Ben Sirach presented his teaching (Nickelsburg 1994:725). The author does not present bis teaching as directly revealed or inspired. Yet, his reflection on the nature of wisdom shows that he views it as a gift that comes down from above (3:13-18). As a teacher, James must share this wisdom with his readers.

No specific situations can be identified which are seen to give rise to the letter's ethical advice. As Dibelius (1975:46) was accustomed to argue from his understanding of James as a paraenetical work. This does not mean that the ethical advice is presented in a vacuum: much of the admonitions must emerge from the background of events that have taken place (such as discrimination against the poor [2:1-12]; or the rich's oppression of the poor [5:1-6]).

\subsection{The importance of this investigation}

This examination of the Epistle of James shows a writing emerging from the world of early Christianity that is home to wisdom, prophetic, apocalyptic and eschatological traditions. James challenges scholarship to discard the focus upon 'pure' traditions as a 
confusion that does not do justice to the evidence. Classifications such as apocalyptic, eschatological, wisdom, prophetic are heuristic tools that remain such: tools to enter into the reality of the past: they do not become the reality itself. To try to classify a writing into solely one category produces a distortion of the evidence. James is in fact a hybrid, which brings many different traditions together, as did 1 Enoch (92-105), and as such provides a possible example for the way other traditions operated in the New Testament world. James brought the traditions together in one way, 1 Enoch in another.

The world of the New Testament knows of another writing, the earliest source behind the Gospels, ' $Q$ ', which bears many similarities to the Epistle of James. It, too, is a hybrid, composed of wisdom, eschatological, prophetical and apocalyptic material. As with James, the wisdom tradition functions as the dominant tradition bringing the others together (Hartin 1991:78-80). The challenge that both James and 1 Enoch (92105 ) would pose to the study of ' $Q$ ' is to view these traditions as existing and developing together. The traditions of wisdom, eschatology and apocalyptic are not to be seen in opposition, but as James and Enoch show, they exist in a relationship as part of the world heritage to which they belong.

\section{Endnotes}

1 For the sake of brevity I shall simply refer to the Epistle of James, as James. By using the designation 'James' I do not mean to imply anything about the identity of the author.

2 This is contrary to the position of Dibelius (1975:207) who states: 'There is no indication of a connection with the preceding section, and the interpretation will reveal that there is no connection in thought either'.

3 In this sense I see the letter emerging from Palestine, from the Judean church, with the notion of the diaspora understood in its normal and natural way, namely referring to those areas outside the land of Palestine. This view differs from that of Dibelius (1975:66) who understood this term in a metaphorical sense by which Christians are identified as the true Israel whose real home is not here on earth, but in heaven, and that Christians on earth are living as it were in the diaspora. (This is the spirit in which 1 Peter addresses his readers in 1:1). However, because of the understanding of the Jewish Christian origin of this epistle and the notion of the 'twelve tribes' as outlined above, I think it best to see the term diaspora being used in its original sense as a reference to "the true Israel (i.e. Jewish Christians) outside of Palestine (i.e. probably in Syria and Asia Minor)' (Davids 1982:64).

4 This phrase 'a day of slaughter' ('́n $\dot{\eta} \mu \varepsilon \dot{\varepsilon} \rho \alpha \sigma \phi \alpha \gamma \hat{\eta} \varsigma$ ) belongs to that prophetic tradition where God's judgment is viewed as a day of slaughter for God's enemies (for example: Is 34:5-8; Jeremia 46:10). What is also significant is that Enoch explicitly connects the judgment of the rich to such a day: 'You ... have become ready for the day of slaughter, and the day of darkness and the day of the great judgment' (1 Enoch 94:9; 97:8-10; 99:15). 
51 Enoch is an interesting literary collection developing over a long period of time. Nickelsburg (1991:51) estimates that it spanned more than three centuries. Not only is it a collection of different texts, but it is also a collection of different traditions that have been forged into a unity: 'Nonetheless, $l$ Enoch is a consciously shaped compilation of traditions and texts, and it is appropirate to search for internal points of commonality (apart from Enochic attribution in most cases) in which the compilers and editors saw the potential for a unity comprised of diversity' (Nickelsburg 1991:52). In particular it provides a good example of the development of traditions, forms and genres during the intertestamental period as no extant piece of literature does. In this sense it occupies a unique position.

6 The translation of 1 Enoch that I quote here is that of Charlesworth 1993:5-89.

7 When using the designation 'Enoch' in this context, I have the Epistle of Enoch (92-105) in mind.

\section{Works consulted}

Adamson, J W 1976. The Epistle of James. Grand Rapids: Eerdmans. 1989. James: The man and his message. Grand Rapids: Eerdmans.

Attrdige, H W, Collins, J J \& Tobin, T H (eds) 1990. Of Scribes and scrolls: Studies on the Hebrew Bible, intertestamental Judaism and Christian origins - presented to John Strugnell. Lanham: University Press of America. (College Theology Society Resources in Religion 5.)

Charlesworth, J H (ed) 1983. The Old Testament pseudepigrapha, vol 1: Apocalyptic literature and testaments. New York: Doubleday.

Collins, J J 1977. Cosmos and salvation: Jewish wisdom and apocalyptic in the Hellenistic age. History of Religions 17, 121-42. 1979. Jewish apocalypses. Semeia 14, 21-59.

1986. Apocalyptic literature, in Kraft, R A, \& Nickelsburg, G W E (eds), Early Judaism and its modern interpreters. Philadelphia: Fortress.

1990. The sage in the apocalyptic and pseudepigraphic literature, in Gammie,

$\mathrm{J} \mathrm{G} \&$ Perdue, L G (eds), The sage in Israel and the ancient near East, 343-354.

Winona Lake: Eisenbrauns.

1991. Genre, ideology and social movements in Jewish apocalypticism, in

Collins, J J \& Charlesworth J H (eds), Mysteries and revelations: Apocalyptic studies since the Uppsala Colloquium, 11-32. Sheffield: Sheffield Academic. (JSP Supp 9.).

1992 [1984]. The Apocalyptic imagination. New York: Crossroad.

1993. Wisdom, apocalypticism, and generic compatibility, in Perdue, L G,

Scott, B B, \& Wiseman, W J (eds), In search of wisdom, 165-185. Westminster: John Knox. 
Crenshaw, J L 1969. Method in determining wisdom influence upon 'historical' literature. JBL 88, 129-42.

- 1976. Studies in ancient Israelite wisdom, selected with a prolegomenon by $J L$ Crenshaw. New York: KTAV Publishing House.

Davids, P H 1982. The epistle of James: A commentary on the Greek text. Exeter: Paternoster.

Dibelius, M 1975. James: A commentary on the epistle of James, tr by M A Williams. Philadelphia: Fortress.

Gammie, J G \& Perdue, L G (eds) ${ }^{\cdot}$ 1990. The sage in Israel and the ancient near East. Winona Lake: Eisenbrauns.

Hartin, P J 1991. James and the ' $Q$ ' sayings of Jesus. Sheffield: Sheffield University Press.

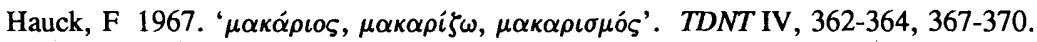

Hellholm, D 1991. Methodological reflections on the problem of definition of generic texts, in Collins, J J \& Charlesworth $\mathrm{J} \mathrm{H}$ (eds), Mysteries and revelations: Apocalyptic studies since the Uppsala Colloquium, 134-163. Sheffield: Sheffield Academic, 134-63. (JSP Supp 9.)

Hoppe, R 1977. Der theologische Hintergrund des'Jakobusbriefes. Würzburg: Echter.

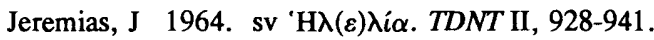

Johnson, L T 1995. The letter of James, in The Anchor Bible. New York: Doubleday.

Knight, D A \& Tucker, G M (eds) 1985. The Hebrew Bible and its modern interpreters. Philadelphia: Fortress.

Kraft, R A, \& Nickelsburg, G W E (eds) 1986. Early Judaism and its modern interpreters. Philadelphia: Fortress.

Laws, S 1980. A commentary on the Epistle of James. London: Black.

Mussner, F 1981. Der Jakobusbrief: Auslegung. 4th edition. Freiburg: Herder.

— 1989. Die ethische Motivation im Jakobusbrief, in Merklein, H (ed), Neues Testament und Ethik, 416-423. Freiburg: Herder.

Nickelsburg, G W E 1977. The apocalyptic message of 1 Enoch 92-105. CBQ 39, 309-328.

1981. Jewish literature between the Bible and the Mishnah. Philadelphia: Fortress.

1982. The epistle of Enoch and the Qumran literature. JSS 33, 333-348.

1991. The apocalyptic construction of reality in 1 Enoch, in Collins, J J \& Charlesworth J H (eds), Mysteries and revelations: Apocalyptic studies since the Uppsala Colloquium, 51-64. Sheffield: Sheffield Academic. (JSP Supp 9.)

— 1992. Enoch, First book of, in Freedman, D N (ed), Anchor Bible Dictionary, 508-516. New York: Doubleday. 
Nickelsburg, G W E 1994. Wisdom and apocalypticism in early Judaism: Some points for discussion, in Lovering, E H (ed), SBL Seminar Papers. Atlanta: Scholars.

Perdue, L G 1994. Wisdom and creation: The theology of wisdom literature. Nashville: Abingdon.

Perdue, L G, Scott, B B, \& Wiseman, W J (eds) 1993. In search of wisdom: Essays in memory of John G Gammie. Westminster: John Knox.

Ropes, J 1916. A critical and exegetical commentary on the epistle of St James. Edinburgh: T \& T Clark.

Schlier, H 1972. sv $\theta \lambda i \beta \omega, \theta \lambda i \psi \iota \varsigma$. TDNT III, 139-148.

Smith, J Z 1975. Wisdom and apocalyptic, in Pearson, B A (ed), Religious syncretism in antiquity: Essays in conversation with Geo Widengren. Missoula: Scholars.

Yarbro Collins, A 1986. Introduction: Early Christian Apocalypticism. Semeia 36, 1-11. 